\title{
鉄筋コンクリート耐震壁のせん断強度に関する解析的研究 ANALYTICAL STUDY ON SHEAR STRENGTH OF REINFORCED CONCRETE SHEAR WALLS
}

\author{
長沼一洋* \\ Kazuhiro. NAGANUMA
}

\begin{abstract}
Shear strength of reinforced concrete shear walls with relatively large height-to-width ratio including multi-story shear walls is discussed based on the results of the finite element analysis. The aim of the present paper is to investigate the effects of parameters such as the amount of reinforcement, characteristics of beams, height-to-width ratio, and loading conditions on the shear strength. It has been found that there is room for improvement in current AIJ Design Guidelines on the estimation of shear strength of walls with large height-to-width ratio and multi-story shear walls.
\end{abstract}

Keywords : multi-story shear wall, finite element method, ultimate strength design 連層耐震壁，有限要素法，終局強度設計

\section{1. 序 論}

鉄筋コンクリート $(\mathrm{RC})$ 造建物の高層化に伴い，耐 震壁を高さ方向に連続した連層耐震壁として配置し，地 震時に脚部で曲げ降伏させる設計が行われるようになっ てきた。このような耐震壁フレーム構造においては, 壁 のせん断破壊の防止が勒性設計上, 極めて重要である。

耐震壁に関しては，これまでに多くの実験が実施され てきたが，それらは比較的低層な建物を想定したシアス パン比が小さいものがほとんどであった。しかし, 最近 では高層建物の連層耐震壁を対象とした実験も行われ始 め, 背高な耐震壁のせん断強度や, 曲げ降伏後の変形能 なぼに関する知見が蓄積されつつある(1)

一方, RC 部材のせん断強度の算定法に関しては, 従 来, 荒川式や広沢式に代表される実験式》に依存してい たが，近年，塑性理論の下界定理に基づいたマクロモデ ルが提案されるようになり ${ }^{8)}$ ，その力学的明快さと実験 式に匹敵する精度が注目を集めている。日本建築学会の 「鉄筋コンクリート造建物の終局強度型耐震設計指針・ 同解説」9) (以後指針と呼ぶ) においても，マクロモデ ルに立脚した算定法が採用されており，せん断抵抗機構 を補強筋が関与するトラス機構とコンクリートのみで形 成するア一千機構の 2 つに分離して, それらの累加強度 としてせん断強度を与える形になっている。しかしなが ら，背の高い壁に関しては，せん断強度の算定法の検証 に必要な実験データが十分には得られていないため，指
針では壁補強筋によるトラス機構の角度は，柱やはりの 場合と異なり, シアスパン比にかかわらず 45 度に固定 されており,また連層耐震壁は各層ごとに設計すること とされている。

一般に, 背の高い壁のトラス機構の角度を 45 度に固 定すると, 安全側ではあるが, 過剩な配筋となる可能性 がある反面, 連層耐震壁の実験との比較では, 設計する 階の階高を用いて算定したせん断強度は実際の強度をか なり上回る之の指摘(0)もあるなど, 現指針における連層 耐震壁のせん断設計法には検討の余地があると言える。

このような背景から, 本研究では内部応力状態等の把 握が容易な有限要素法 ( FEM) により, 連層耐震壁を 含む比較的幅高さ比 $(h / l: h$ は高さ, $l$ は幅) の大き な耐震壁を中心に, せん断強度に関する解析的な検討を 行い,より合理的な設計法に向けての基礎的デー夕を得 ることを目的とした。

\section{2. 既往の研究と本研究における検討内容}

壁のせん断強度への影響因子の内, 補強筋量と軸力に 関しては, それらのせん断強度への奇与には限界がある こと, また軸力の効果は補強筋が少ないものほど, 顕著 であることなぼが知られている99。

白石ら ${ }^{111.12)}$ はFEM 解析と実験により, せん断強度の 増大には壁の横筋量の影響が大きく, シアスパン比が大 きいものほど, その効果が顕著であることを示した。植

* 大林組技術研究所数值解析研究室 研究員 . 工修 Research Engineer, Technical Research Institute, Obayashi, Corp., M. Eng. 
松ら ${ }^{13}$ は解析により，壁のせん断耐力にはシアスパン比 より壁の幅高さ比の影響が大きいことを示した。望月 ら (4)は側柱の拘束が壁のせん断破壊性状に及ぼす影響を 実験と解析の両面から検討した。狩野・高木ら ${ }^{15}$ は 4 層 壁の実験により，中間ばりを除いても水平補強筋を用い ることで同等の耐力が得られることを示した。鈴木 ${ }^{16)}$ は 解析により，柱降伏先行型の連層耐震壁の耐力に及ぼす はり主筋の影響は大きく,特にはり主筋が無い場合には， 水平力が片押し載荷より押し引き載荷の方が耐力が低下 することを示した。佐藤ら"7'は加力方法を変えた 3 層壁 の実験を行い，頂部集中載荷に比べ各層分布加力の方が 耐力が上昇することを示した。井上ら ${ }^{18)}$ は既往のマク口 モデルと FEM による解析を行い，力の流れゃ各機構 の分担率などを比較し，側柱の分担を適切に考慮するこ との重要性を指摘した。飯塚・野ロ ${ }^{191}$ はシアスパン比が 2.0 の壁におけるトラス機構の角度は, 指針による 45 度をかなり下回ることを解析により示した。この他，多 くの研究があるが, シアスパン比が 1.5 以上，あるいは 3 層を超える連層耐震壁や各層加力を対象とした研究は 少ないのが現状である。

本研究では, 幅高さ比が比較的大きな壁を主対象に, 耐震壁のせん断強度への影響因子として壁の幅高さ比, 壁筋量, 側柱の主筋量, 頂部ばりの剛性, 中間ばりの有 無と主筋量，および加力方法に着目して検討する。なお 側柱の曲げ降伏および壁板の破壊に先行するはりや側柱 の破壊は生じない条件下でのせん断強度に限定する。

\section{3. 解析精度の検証}

本研究のように，数値実験的手法により検討を進める 場合には, 解析結果の信頼性の確認が不可欠である。筆 者はせん断破壊を生じる RC 面部材の解析精度の向上 を目的として，平板実験の結果に基づく FEM 解析モ デルを誘導し，要素レベルでの検証を行った20)。さら に,これらのモデルを用いて地震時荷重を受ける耐震壁 の解析手法を提案し，その適用性を検討した結果，既往 の様々なタイプの耐震壁の耐力を精度良く評価できるこ とを示した211。しかし，適用性の検討に用いた試験体 57 体の内, 45 体はシアスパン比が 1.0 以下と小さく, 連層耐震壁は 2 層と 3 層が各 10 体ずつであり，背の高 い耐震壁に関しては解析精度の検証が十分とはいえな い。そこで，既往の連層耐震壁を含む比較的シアスパン 比の大きな耐震壁の実験より，せん断破壊を生じた試験 体を中心に 47 体を新たに選定し,解析精度の検証を行っ た。

試験体のモデル化は既報21)で述べた方法に従い，4節 点平面応力要素により, 各層の壁板が正方形に近い要素 で 50 分割以上となるようにした。鉄筋は等価な一方向 剛性層に置換して平面応力要素に重好合わせた。コンク
リートは直交異方性モデルにより，ひびわれ後の圧縮特 性, テンションスティフニング特性, およびひびわれ面 のせん断伝達特性は平板実験結果に基づくモデル201を用 いた。鉄筋の応力〜ひずみ関係は bilinear とした。

表一1に解析対象試験体の諸元之最大荷重に閂する実 験と解析の比較を示す。実験では，壁板コンクリートの 圧壊により耐力が決定したものが多く，側柱の破壊や主 筋の降伏を伴うもの，壁筋の破断が生じたものもある。 実験の破壊モ一ドが報告されている試験体に関しては, 壁筋の破断を除き，解析でもほぼ同様の性状を示した。 解析結果の例として, 荷重一層間変位曲線と破壊状況に 関する実験結果との比較を図一1 および図一-2に示す。

最大荷重の解析值に対する実験值の比は $0.85 \sim 1.16$ の範囲にあり, 平均值 1.01 ，変動係数 0.073 であった。 既報21)での検証結果に比較すると，やゃ変動係数が大き いが, 最大荷重の解析精度としては良好と考えられる。

なお，壁横筋のひずみは耐震壁のせん断抵抗機構に関 わる重要なデータであるが, 解析対象試験体の内, 壁横 筋のひずみ分布が報告されているものは NW-1 と NW2 の 2 体のみであった。これら 2 本の横筋のひずみは, 解析では実験とほほ対応する部分はあるものの，実験值 の $1 / 2$ 程度と小さい箇所も見られた。一般に鉄筋のひず みゲージの值はひびわれ近傍では局所的に大きな值を示 す場合があることから，分布ひびわれを仮定した解析で 得られる平均的なひずみとは差が生じ得るものと思われ る。

以後の検討はすべて平面応力解析で行うが，側柱にお ける帯筋の拘束効果や，柱はり部材による壁板への面外 拘束の影響など，平面応力解析では考慮されていない点 があることをあらかじめ付記しておく。

\section{4. 加力方法と頂部はり剛性がせん断強度に及ほすす影響}

耐震壁の実験では, 水平力は頂部のはりに対して片押 し載荷，または両側で押し引き同時載荷されることが多 いが，構造物中の耐震壁では，地震力は上層の柱と林ス ラブからの入力が支配的と考えられ，分布荷重と見なす のが最も実際に近いと思われる。一方，頂部のはりに対 してはコンクリート圧縮束の反力が作用するため，はり の剛性と強度が不十分な場合には，壁板のせん，断強度到 達以前に耐力が決定してしまうことが考えられる。連層 耐震壁の場合は，一般に上層部ほど，壁の損傷が小さく なるため，想定している層のはりに対する上确の壁から の拘束が期待できる場合もある。本章では，加力方法と 頂部のはりの剛性の違いが, 耐震壁のせん断強度に及ぼ す影響を検討する。

\section{1 解析対象モデルと加力方法}

解析対象はできるだけ実際の構造物に即したものとす るため，指針9)の設計例 1 に示されている 6 階建の建物 
表一1 連層耐震壁を含む比較的シアスパン比の大きな耐震壁試験体の諸元および実験と解析の耐力比較

\begin{tabular}{|c|c|c|c|c|c|c|c|c|c|c|c|c|c|c|c|c|}
\hline \multirow[b]{2}{*}{ 試馬㑒体 } & \multirow{2}{*}{ 虞 } & \multirow{2}{*}{$\begin{array}{l}\text { 殒 } \\
\text { 方法 }\end{array}$} & \multirow{2}{*}{$\begin{array}{l}\text { シアス } \\
\text { パン比 }\end{array}$} & \multirow{2}{*}{$\begin{array}{c}\mathrm{cO}_{\mathrm{a}}^{\dot{2}^{2}} \\
\mathrm{kgf} / \mathrm{cm}^{2}\end{array}$} & \multicolumn{3}{|c|}{ 壁 板 } & \multicolumn{3}{|c|}{ 柱 } & \multicolumn{2}{|c|}{ 中間ばり } & \multirow{2}{*}{$\begin{array}{l}\text { 軸席力 } \\
\mathrm{kgf} / \mathrm{cm}^{2}\end{array}$} & \multicolumn{2}{|c|}{ 最大荷重。 } & \multirow{2}{*}{$\begin{array}{l}\text { 文 } \\
\text { 献 } \\
\text { No. }\end{array}$} \\
\hline & & & & & $e \times t^{-3}$ & 壁笳比 & 降优点 & $B \times \dot{D}^{3}$ & 主筋比 & 帯筋比 & $B \times \ddot{D}^{3}$ & 主能比 & & 実験值 & 実験値 & \\
\hline $\begin{array}{l}302 \\
402 \\
404 \\
406 \\
\end{array}$ & 3 & 各層 & 1.02 & $\begin{array}{l}267 \\
230 \\
193 \\
244 \\
\end{array}$ & $45 \times 3$ & $\begin{array}{l}0.20 \\
0.21 \\
0.40 \\
0.61\end{array}$ & \begin{tabular}{|c|}
$\mathrm{kgf} / \mathrm{cm}^{2}$ \\
2650 \\
2280 \\
2280 \\
2280 \\
\end{tabular} & $12 \times 5$ & $\begin{array}{c}\% \\
3.20 \\
4.30 \\
4.30 \\
4.30\end{array}$ & $\begin{array}{c}\% \\
1.00 \\
1.60 \\
1.60 \\
1.60\end{array}$ & $8 \times 5$ & 1.30 & $\mathrm{kgt} / \mathrm{cm}^{2}$ & $\begin{array}{c}\text { tf } \\
9.51 \\
11.3 \\
11.5 \\
11.5\end{array}$ & \begin{tabular}{|c|} 
解析值 \\
1.09 \\
$: 1.08$ \\
1.11 \\
1.04
\end{tabular} & .22 \\
\hline $\begin{array}{l}8101 \\
8102 \\
8103 \\
8104 \\
8105 \\
8106 \\
8107 \\
8108 \\
\end{array}$ & 3 & 各原 & 1.02 & $\begin{array}{l}245 \\
244 \\
259 \\
293 \\
257 \\
260 \\
285 \\
250\end{array}$ & 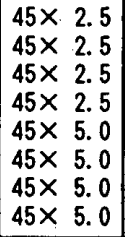 & $\begin{array}{l}0.25 \\
0.25 \\
0.25 \\
0.25 \\
0.12 \\
0.12 \\
0.12 \\
0.12\end{array}$ & 2650 & $12 \times 5$ & 6.40 & 1.57 & $\begin{array}{c}\bar{z} \\
12 \times 5 \\
12 \times 5 \\
\overline{-} \\
12 \times 5 \\
12 \times 5\end{array}$ & $\begin{array}{c}\overline{(5-4 \phi)} \\
- \\
2.10 \\
- \\
(5-4 \phi) \\
-10 \\
2.10\end{array}$ & 40.0 & $\begin{array}{l}9.06 \\
9.90 \\
12.3 \\
12.0 \\
15.2 \\
16.6 \\
: 15.8 \\
14.2\end{array}$ & $\begin{array}{l}1.02 \\
0.94 \\
1.14 \\
0.96 \\
1.16 \\
1.04 \\
1.10 \\
0.85\end{array}$ & 23 \\
\hline $\begin{array}{l}B 4-W 02 \\
\text { B4-W07 } \\
\text { B4-W12 } \\
\text { B6-W07 } \\
\text { B8-W02 } \\
\text { B8-W07 } \\
\text { B8-W12 }\end{array}$ & 3 & 頂部 & 1.46 & $\begin{array}{l}272 \\
286 \\
283 \\
282 \\
272 \\
282 \\
291 \\
\end{array}$ & $57 \times 2.5$ & $\begin{array}{l}0.25 \\
0.68 \\
1.19 \\
0.68 \\
0.25 \\
0.68 \\
1.19\end{array}$ & 3490 & $8 \times 8$ & 4.00 & 0.50 & $5 \times 7$ & $\begin{array}{l}2.97 \\
2.97 \\
2.97 \\
4.46 \\
5.94 \\
5.94 \\
5.94\end{array}$ & 20.0 & $\begin{array}{l}12.9 \\
13.1 \\
14.4 \\
14.1 \\
14.1 \\
14.6 \\
14.4\end{array}$ & $\begin{array}{l}1.09 \\
1.01 \\
1.05 \\
1.07 \\
1.15 \\
1.09 \\
1.00\end{array}$ & 24 \\
\hline $\begin{array}{l}77 \text { W202 } \\
77 W 203 \\
77 W 205 \\
77 W 206\end{array}$ & 3 & 頂部 & 1.28 & $\begin{array}{l}226 \\
174 \\
181 \\
155\end{array}$ & $105 \times 4.5$ & $\begin{array}{l}0.72 \\
0.72^{\circ}+1 \\
0.24 \\
0.24\end{array}$ & 5398 & $15 \times 15$ & 2.53 & 0.28 & $15 \times 15$ & 1.27 & $\begin{array}{r}30.0 \\
30.0 \\
0.0 \\
70.0\end{array}$ & $\begin{array}{l}25.7 \\
21.4 \\
17.3 \\
23.6\end{array}$ & $\begin{array}{l}0.93 \\
0.92 \\
0.92 \\
0.99\end{array}$ & 25 \\
\hline $\begin{array}{l}78 W 207 \\
78 W 208\end{array}$ & 3 & 頂部 & 1.28 & $\begin{array}{l}194 \\
181\end{array}$ & $\begin{array}{l}105 \times 3.0 \\
105 \times 6.0\end{array}$ & 0.24 & 4596 & $15 \times 15$ & 2. 53 & 0.28 & $15 \times 15$ & 1.27 & 30.0 & $\begin{array}{l}20.4 \\
24.0\end{array}$ & $\begin{array}{l}1.08 \\
0.99\end{array}$ & 26 \\
\hline $\begin{array}{l}79 W 402 \\
79 W 403\end{array}$ & 3 & 頂部 & 1.02 & $\begin{array}{l}245 \\
206\end{array}$ & \begin{tabular}{|l|}
$105 \times 4.5$ \\
$105 \times 6.0$ \\
\end{tabular} & $\begin{array}{l}0.72 \\
0.24 \\
\end{array}$ & 2337 & $15 \times 15$ & 4. 52 & 0.28 & $15 \times 15$ & $\begin{array}{l}1.27 \\
2.26\end{array}$ & 30.0 & $\begin{array}{l}33.8 \\
33.4\end{array}$ & $\begin{array}{l}1.03 \\
1.05\end{array}$ & 17 \\
\hline $\begin{array}{l}79 W 209 \\
79 W 210\end{array}$ & 3 & 各層 & 1.28 & $\begin{array}{l}303 \\
251 .\end{array}$ & $\begin{array}{l}105 \times 4.5 \\
105 \times 3.0\end{array}$ & 0.24 & 2681 & $15 \times 15$ & 2. 53 & 0.28 & $15 \times 15$ & 1.27 & 30.0 & $\begin{array}{l}28.3 \\
23.2\end{array}$ & $\begin{array}{l}1.00 \\
0.93\end{array}$ & 17 \\
\hline $\begin{array}{l}\text { No. } 5 \\
\text { No. } 6 \\
\text { No. } 7 \\
\text { No. } 8\end{array}$ & 1 & 頂部 & i. 50 & $\begin{array}{l}200 \\
225 \\
225 \\
200\end{array}$ & $88 \times 4.5$ & $\begin{array}{l}0.20 \\
0.20^{* 7} \\
1.20^{* 7} \\
1.20\end{array}$ & 2950 & $15 \times 15$ & 7.06 & 0.42 & - & - & 0.0 & $\begin{array}{l}14.1 \\
15.3 \\
24.3 \\
27.5\end{array}$ & $\begin{array}{l}0.99 \\
0.85 \\
0.98 \\
1.10\end{array}$ & 12 \\
\hline $\begin{array}{l}\text { 89SW03 } \\
89 \text { SW06 }\end{array}$ & 1 & 頂部 & 1.87 & $\begin{array}{l}259 \\
279\end{array}$ & $\begin{array}{l}60 \times 3.5 \\
60 \times 3.7\end{array}$ & $\begin{array}{l}0.93 \\
0.88\end{array}$ & 4994 & $15 \times 15$ & $\begin{array}{l}6.19 . \\
4.42\end{array}$ & 0.28 & $-\cdot$ & - & 0.0 & $\begin{array}{l}19.9 \\
20.8\end{array}$ & $\begin{array}{l}0.96 \\
0.99\end{array}$ & 1 \\
\hline $\begin{array}{l}N W-1 \\
N W-2\end{array}$ & 1 & 頂部 & $\begin{array}{l}2.00 \\
1.33\end{array}$ & $\begin{array}{l}894 \\
955\end{array}$ & $130 \times 8$ & 0.53 & 10216 & $20 \times 20$ & 2. 14 & $0.70^{* 8}$ & - & - & $\begin{array}{l}97.8 \\
97.8\end{array}$ & $\begin{array}{l}108 \\
150\end{array}$ & $\begin{array}{l}1.05 \\
1.04\end{array}$ & 2 \\
\hline $\begin{array}{l}N W-3 \\
N W-4 \\
N W-5 \\
N W-6\end{array}$ & 1 & 頂部 & 2.00 & $\begin{array}{l}566 \\
557 \\
615 \\
665 \\
\end{array}$ & $130 \times 8$ & $\begin{array}{l}0.27 \\
0.27 \\
0.53 \\
0.53\end{array}$ & 7685 & $20 \times 20$ & $\begin{array}{l}2.14 \\
2.85 \\
2.85 \\
3.81\end{array}$ & $0.49^{\circ} \mathrm{B}$ & - & - & $\begin{array}{l}76.1 \\
87.0 \\
76.1 \\
87.0\end{array}$ & $\begin{array}{l}73.2 \\
80.0 \\
91.8 \\
108\end{array}$ & $\begin{array}{l}0.95 \\
0.90 \\
1.00 \\
0.99\end{array}$ & 3 \\
\hline $\begin{array}{l}\text { W2BFNO } \\
\text { W2BFN1 } \\
\text { W2SFN2 }\end{array}$ & 2 & 各層 & 0.80 & $\begin{array}{l}286 \\
306 \\
312\end{array}$ & $88 \times 5^{.0}$ & $\begin{array}{l}0.26^{* 0} \\
0.26^{* 0} \\
0.43^{* 0}\end{array}$ & 3825 & $15 \times 12$ & $\begin{array}{l}1.58 \\
1.58 \\
4.77\end{array}$ & 0.33 & $15 \times 15$ & 1.26 & $\begin{array}{r}0.0 \\
30.6 \\
52.0\end{array}$ & $\begin{array}{l}15.0 \\
21.7 \\
47.2\end{array}$ & $\begin{array}{l}0.94 \\
0.97 \\
1.07\end{array}$ & 4 \\
\hline $\begin{array}{l}\text { W4BFN0 } \\
\text { W4BFN1 } \\
\text { W4SFN2 }\end{array}$ & 4 & 各㕆 & 1.50 & $\begin{array}{l}333 \\
372 \\
352\end{array}$ & $88 \times 5^{-0}$ & $0.43^{\circ} \circ$ & 3825 & $15 \times 12$ & $\begin{array}{l}2.82 \\
2.82 \\
8.46\end{array}$ & 0.33 & $15 \times 15$ & 2. 26 & $\begin{array}{r}0.0 \\
37.2 \\
58.7\end{array}$ & $\begin{array}{l}16.0 \\
21.4 \\
42.6\end{array}$ & $\begin{array}{l}0.94 \\
1.03 \\
1.01\end{array}$ & 4 \\
\hline $\begin{array}{ll}* 1 & \mathrm{~J} \\
\text { *2 } & \sqsupset\end{array}$ & 部: & 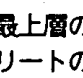 & $\begin{array}{l}\text { Dはりにf } \\
\text { D一軸厓 }\end{array}$ & $\begin{array}{l}\text { 押し臷荷 } \\
\text { 摍強度 }\end{array}$ & $\begin{array}{l}\text { 各居 : 迹 } \\
\text { *3 } e \text { : }\end{array}$ & $\begin{array}{l}\text { 兰三角形S } \\
\text { : 壁の内泛 }\end{array}$ & $\begin{array}{l}\text { 分布で各原 } \\
\text { 去 } t: \text { 壁 }\end{array}$ & $\begin{array}{l}\text { 罣のはり } \\
\text { 童晕 B }\end{array}$ & $\begin{array}{l}\text { 片押し或 } \\
\text { 幅 D: }\end{array}$ & 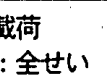 & & & $\begin{array}{l}\text { 平均 } \\
\text { 変動 }\end{array}$ & $\begin{array}{l}\text { 匀值 } \\
\text { 係数 }\end{array}$ & $\begin{array}{l}1.01 \\
0.07\end{array}$ & \\
\hline
\end{tabular}

$Q(t f)$

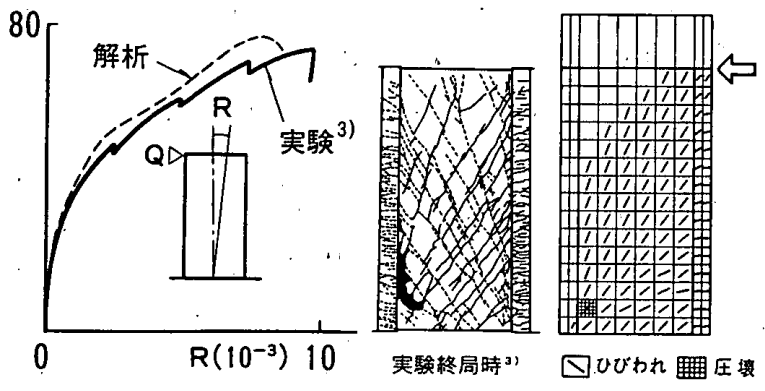

図一1 NW-3 試験体 ${ }^{3 i}$ の荷重一変形関係と破壊状況の比較
$Q(t f)$

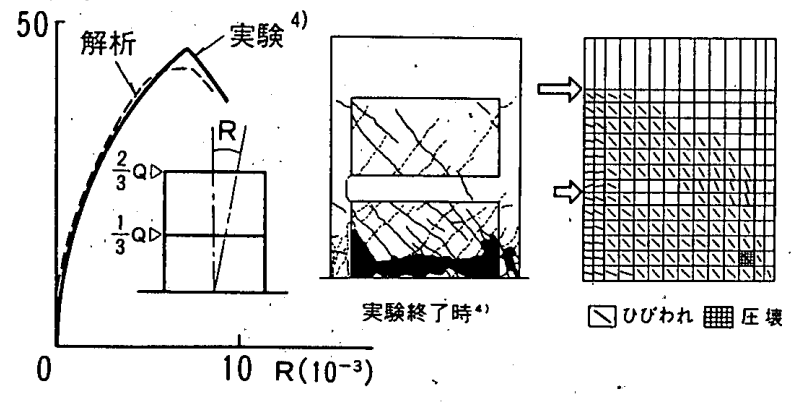

図一2 W 2SF-N 2 試験体 ${ }^{4}$ の荷重－変形関係亡破壊状況の比 較 

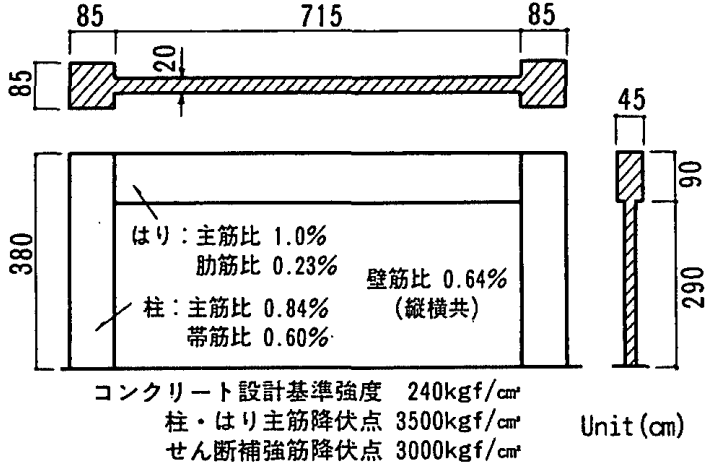

図一3 解析対象モデルの 1 層部

の連層耐震壁を選んだ。1 層部分の形状・寸法を図一3 に示す。壁の頂部における諸条件の差は，壁の高さが小 さいものほど，顕著となると考えられるため，解析では 壁の高さを 1 3 層の範囲で変化させた。また, 壁のせ ん断強度を把握するため, 柱主筋は降伏しないものとし た。さらに条件の単純化のため, 中間ばりおよび鉛直軸 力は存在しないものとした。

解析パラメータは以下のとおりである。

・壁の幅高さ比：0.42/0.89/1.37

・頂部はりの特性：設計例どおり/剛体

-上層による拘束：無し/1 層分 $(3.8 \mathrm{~m})$ をモデル化

-水平力載荷方法：片押儿載荷/分布載荷

水平力の作用高さは, はり成の中心とし, 分布載荷の 場合は, 水平力の作用高さにある各節点から PC 鋼棒 に相当するトラス要素を伸ばし，それらを水平方向の延 長線上に設けた剛体に連結して，その剖体に水平力を載 荷する方法を用いた。この方法では，トラス要素の剛性 を小さくすることで, はりの材軸方向の変形拘束を低娍 することが可能で,さらに各節点の水平方向剛性に応じ て荷重分布が決まることから, 部分的な破壊に伴う荷重 の再配分を考慮することができる。

解析ケース名とパラメータの関係を以下に示す。

例） A 11：片押し載荷 A 12：分布載荷

$A 13 ：$ 分布載荷・上部 1 層考慮

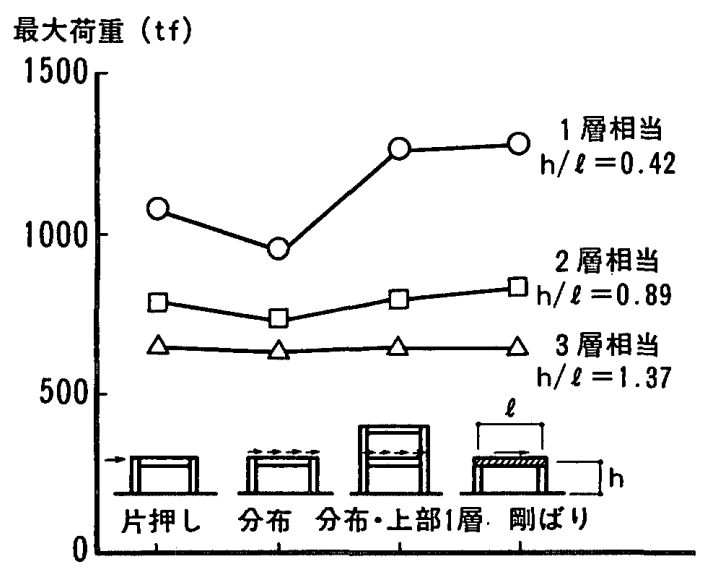

図一4 加力方法とはり凬性の違いによる最大荷重の比較

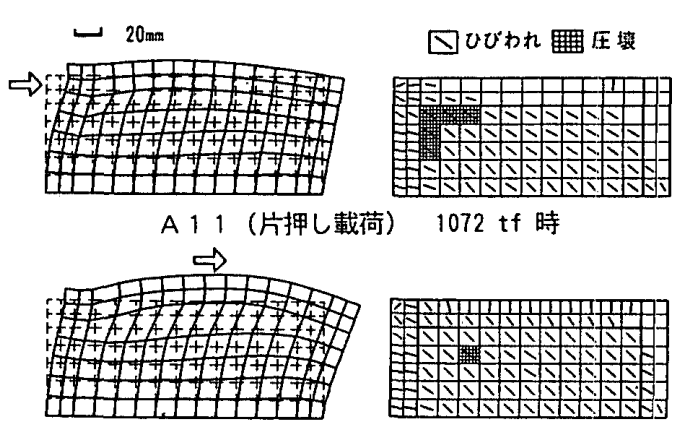

A 12 (分布載荷) $927 \mathrm{tf}$ 時

$\Rightarrow$

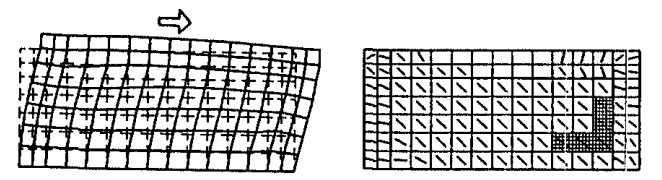

A 13 (分布載荷・上部 1 層考慮) $1230 \mathrm{tf}$ 時

図一5 変形モードと破壊状況の比較

\section{A 14 ：剛体ばり}

なお，ケース名の最初のAはシリーズ名, 2 番目の 1 は 壁の高さが設計例の 1 層分に相当することを表してお り，以後の解析ケースにおいても同様である。

\section{2 解析結果の検討}

図-4に最大荷重の比較を示す。壁の幅高さ比の違い による最大荷重の差に関しては後節で検討する。壁の高 さが 1 層相当の場合, 上部の 1 層を考慮したものは，は りを㴊体としたものとほぼ等しい耐力を示したが，片押 し載荷ではやや耐力が低く, 分布載荷では, さらに低い 耐力を示した。幅高さ比が大きくなると, 加力方法やは りの㴊性の違いによる耐力差が小さくなる傾向がある。

壁の高さが 1 層相当の場合について，はりを剛体とし たA14を除く 3 ケースの最大荷重付近における変形 モードと破壊状況を図一5に示す。A14 と関しては，は りのひびわれが生じない点を除いて A13 とほ:等しい 結果であった。片押し載荷のA11では, 加力点に近い 壁のコンクリートに最も高い応力が生じ, この部分の圧 壊が耐力を決定している。分布載荷のA12では, はり の伸びが大きく，ひびわれによりはりの剛性が低下する ため, 壁板コンクリートの圧縮束の反力により, 中央部 が上に膨らむ変形モードを示している。はりの変形によ り壁板の鉛直および水平方向の拘束度が娍少するため, 耐力が低くなるものと考えられる。上部の 1 層を考慮し た A 13 に関しては図一 5 で下層部のみを示している。 $\mathrm{A} 12$ 亡同じく分布載荷であるが，上層の拘束により， はりのひびわれや変形が抑えられている。壁板コンク リートの応力は全体曲げによる王縮力が作用する圧縮側 柱の近傍で大きく，この部分の圧壊によって最大耐力に 至っている。

一方，壁の幅高さ比が大きくなると，はりによる拘束 の及ぶ範囲が相対的に減少し，全体曲げによる圧縮力が 
大きくなるため, A 31〜34ではいずれも壁中腹部での 横筋の降伏後に, 圧縮側柱の下部付近の壁板コンクリー トの圧壊が生じており，耐力差がほとんよ゙見られない。

以上より, 頂部のはりの剛性か壁のせん断強度に及ぼ す影響は, 壁の幅高さ比の増大とともに小さくなり, 上 層による拘束効果は, 剠体ばりにより模擬可能といえる。

\section{5. 側柱の主筋量がせん断強度に及ぼす影響}

前章では柱主筋の降伏を防止するために，降伏点を十 分高く設定したが，柱主筋量を增す方法も考えられる。 ただし, 主筋量の增加に伴い, 柱の軸方向変形量が減少 し, 全体変形に占める曲げ変形の比率が小さくなる。本 章では, 側柱の主筋量の差が, 柱主筋の降伏に先行する 耐震壁のせん断強度に及ぼす影響を検討する。

\section{1 解析対象モデルと加力方法}

前章と同じく指針の設計例 1 の 1 層部分を解析対象之 した。ただし，全体変形に占める曲げ変形の比率は壁の 幅高さ比の増大に伴って大きくなることから, 壁の高さ を1〜6層で変化させた。頂部のはりは判体とし, 他は 前章と同条件で解析した。比較のためシアスパン比が $1 / 2$ となる逆対称曲げせん断加力による解析も実施し た。

解析パラメータは以下のとおりである。

-側柱の主筋比：0.84\%～10\%（主筋全断面積比）

・壁の幅高さ比：0.42元2:.79

・加力方法：片持ばり型/逆対称曲げせん断型

なお, 側柱の主筋は弾性を仮定し, 設計例 1 の 1 層柱 脚での主筋比 $0.84 \%$ を基準しとて, それを超える分は, 柱の芯鉄筋として柱成の中心位置にトラス要素を配置し てモデル化した。これは, 柱主筋比の増大による柱自体 の曲げ耐力上泉の影響を小さくするためである。

解析ケース名はB10のようにすべて Bで始まり，2 番 目の数字は前章と同じく壁の高さを表し, 3 番目の数字 は次の要領で柱主筋比を表す。

$$
\begin{array}{lll}
0: 0.84 \% & 1: 2.39 \% & 2: 3.92 \% \\
3: 5.44 \% & 4: 10 \% &
\end{array}
$$

\section{2 解析結果の検討}

図一6に最大荷重の比較を示す。柱主筋量の増加に伴 い, 最大荷重も上昇する傾向が見られ，特に壁の高さが 低いもの，および片持ばり型加力の場合に顕著である。

図一7 に壁の高さが 2 層相当で, 柱主筋比が $0.84 \%$ の B20 と $5.44 \%$ の B 23 の解析結果の比較を示す。柱 主筋量が少ないB 20 では, 壁の縦筋の降伏が顕著で, 中立軸位置がかなり圧縮側柱に近ついている。壁板内の 圧縮応力は, 柱主筋量が多い B 23 では比較的広範囲に 分布しているが, B20では圧縮側柱下部付近の壁板に 圧縮応力が集中し，ここの部分のコンクリートの圧壊に よって耐力が決定している。すなわち, 引張側柱の軸方

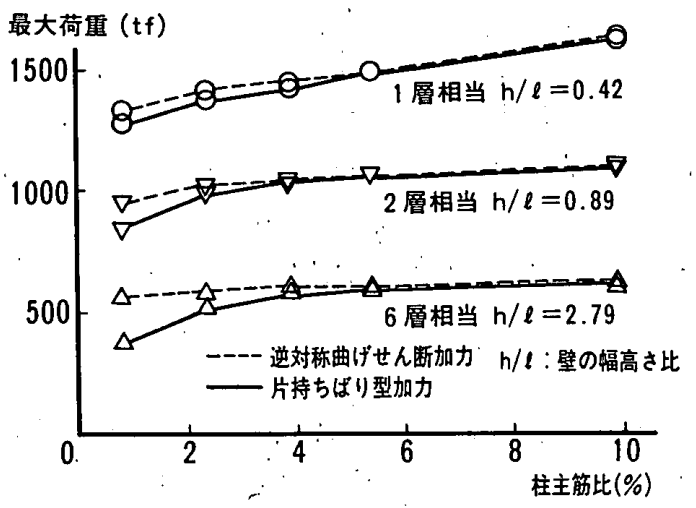

図一6 柱主筋比の違いによる最大荷重の比較
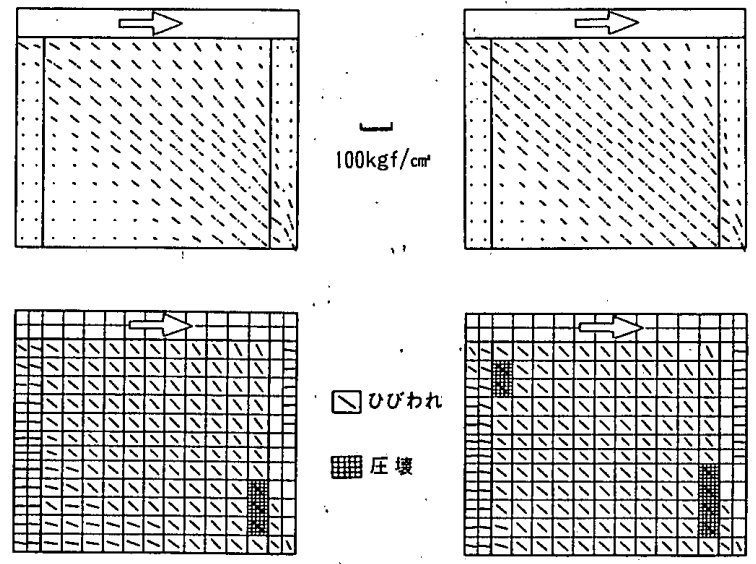

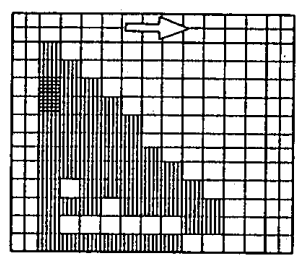

B20 (䄇主筋比 $0.84 \%$ ) $716 \mathrm{tf}$

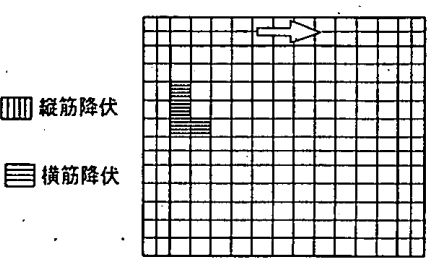

B23（柱主筋比 5.44\%) $964 \mathrm{tf}$
图一7柱主筋比の違いによる解析結果の比較

向伸び量の增大は, 圧縮側下部の壁板の応力集中度を高 めることになり，高強度鉄筋の使用による柱主筋量の低 減に際しては注意が必要と言える。ただし, 解析では最 大荷重時の変形量は柱主筋量の増大に伴い小さくなる傾 向が明暸に見られたことから, 柱主筋量の低減は勒性能 向上の面からは効果があると言える。

逆対称曲げせん断加力の場合は，片持ばり型加力の場 合より引張側柱の軸方向変形が抑えられるため, 耐力が 高くなると考えられる。例えば，壁の高さが 6 層相当の モデルでは, 逆対称曲げ.せん断加力で柱主筋比が 0.84 $\%$ の耐力は, 片持ばり型加力で柱主筋比が $3.92 \%$ の耐 力にほぼ等しく, 耐力時の引張側柱の平均軸方向ひずみ も両者とも $1600 \mu$ 程度で等しい。

片持ばり型加力の場合でも, 柱主筋比が $5.44 \%$ 以上 では逆対称曲げせん断加力との耐力が等しくなり, シア スパン比の差の影響が見られなくなる。また壁の高さが 2 層および 6 層相当の場合には, 柱主筋比の増大による 
耐力上昇に頭打ちが見られる。一方，壁の高さが 1 層相 当のモデルでは, 曲げ変形成分が小さいため, 加力方法 による耐力差は小さいが，柱主筋比の増大に伴い，耐力 がほぼ線形的に上昇している。これは，壁の高さが低い 場合は，柱はりによる拘束効果が現れやすく，柱の軸方 向剛性の上昇が拘束効果を増大させるためと考えられ る。

\section{6. 壁筋量と壁の幅高さ比がせん断強度に及ぼす影響}

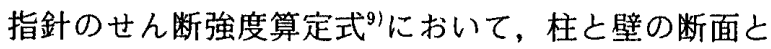
材料強度を固定すると，せん断強度は基本的にトラス機 構にかかわる壁筋比と，アーチ機構にかかわる壁の幅高 さ比により決定される。本章では壁筋比と壁の幅高さ比 がせん断強度に及ぼす影響を検討する。

\section{1 解析対象モデル}

解析対象と解析条件は前章と同様であるが，加力は片 持ばり型とし, 側柱の主筋比は前章の検討で加力方法に よる影響が無くなる $5.44 \%$ とした。壁筋比は指針によ る補強限界を上限とし，壁の高さは $1 \sim 6$ 層で変化させ た。解析ケース名はC 42 のようにすべてCで始まり，2 番目の数字は前章までと同様に壁の高さを表し， 3 番目 の数字は次のように壁筋比を表す。
$0: 0.0 \%$
$1: 0.32 \%$
$2: 0.64 \%$
$3: 0.95 \%$
$4: 1.27 \%$
$5: 2.32 \%$

\section{2 指針式之解析結果の比較検討}

図一8に壁の高さが 2 層と 4 層相当のものに関して,
壁筋比を変化させた場合のせん断強度の解析結果，指針 式，および広沢式の比較を示す。図中にはトラス機構負 担分も示した。解析におけるトラス機構負担分は，井上 らの方法 ${ }^{271}$ に従って算定したが，後述するようにトラス 機構負担分は壁の高さ方向で変化するため，トラス機構 が最大となる水平断面（壁の中腹付近）の值を採用した。 また，壁板部分のみで算定したため，側柱の負担分の一 部を含む指針のトラス機構とはやや異なる。指針では卜 ラス機構の角度 $\phi$ を 45 度 $(\cot \phi=1.0)$ としているが, 比較のため柱やはりと同様に $\cot \phi \leqq 2.0$ の条件の下で $\cot \phi$ の最小值を用いた場合の結果も示した。以後は便 宜的に柱やはりと同様に $\cot \phi \leqq 2.0$ の場合を A 法, $\cot \phi=1.0$ の場合を B 法と呼ぶ。

指針ではトラス機構負担分は壁の高さに無関係で, アーチ機構負担分は壁が高くなると減少する。壁筋比の 増大に伴い壁の高さによる差が小さくなるが，A.法はB 法より常に高目の強度を与え，その差は壁が高いものほ ぼ大きく，壁筋比が補強限界の $1 / 2$ 程度で最も顕著とな る。

解析によるせん断強度は，壁の高さが 2 缯相当の場合 は指針式を常に上回るが,壁の高さが 4 層相当の場合は, 壁筋比が $2.32 \%$ では指針式を下回り，それ以下のケー スでは A 法と B 法の間にある。指針と同様に，壁筋比の 増大に伴い，せん断強度を占めるトラス機構の比率が大 きくなるが，トラス機構負担分は，指針のように壁筋比 と線形関係になく，壁筋比の増大に伴い上昇率が鈍化す

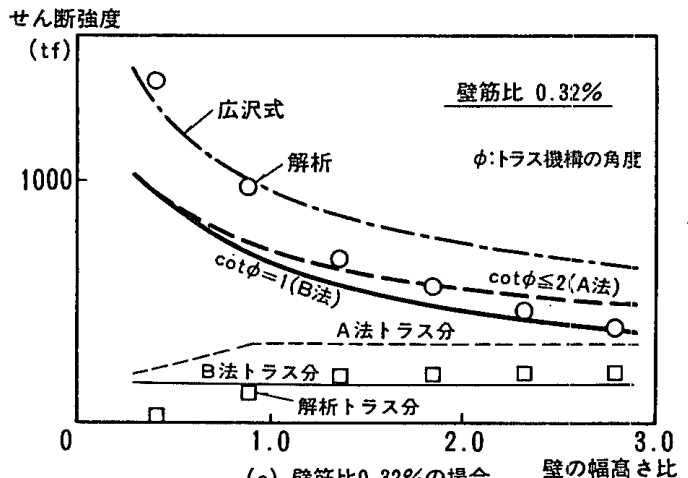

(a) 壁筋比 $0.32 \%$ の場合

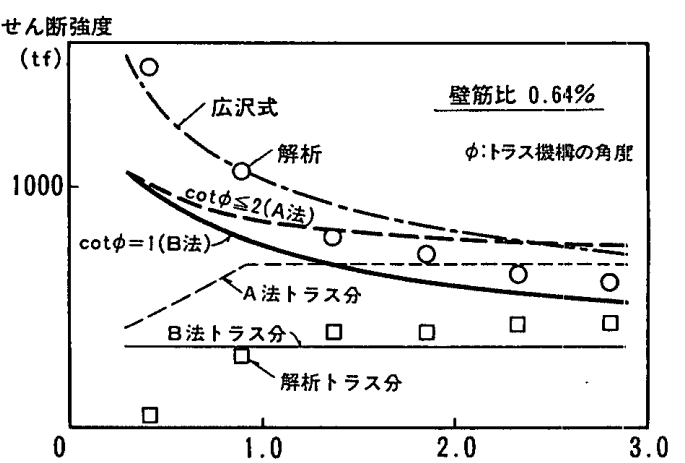

(b) 璧筋比0.64\%の場合

図一9＼cjkstart壁の幅高さ比がせん断強度に及ぼす影響 

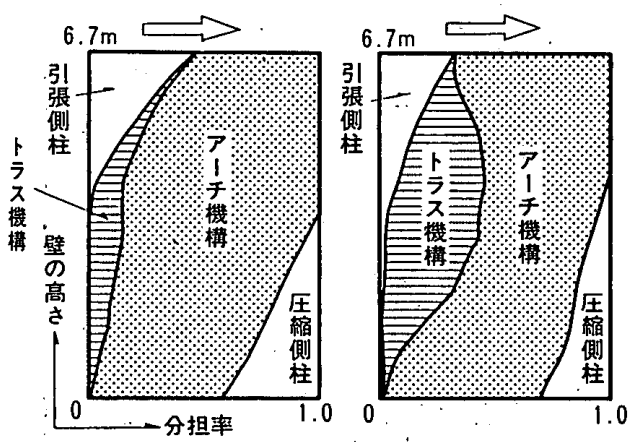

(a) C21(壁笳比0.32\%) (b) C23(壁筋比0.95\%)

図一10 壁の幅高さ比が 0.89 (2 層相当) の場合の各機構と側 柱のせん断力分担率

る傾向がある。壁筋比が $2.32 \%$ の場合に解析のトラス 機構負担分が指針式をかなり下回った原因は，解析では 横筋が降伏せず，壁板コンクリートの圧壊で耐力が決定 したためである。

広沢式は壁の高さが 2 層相当の場合に解析結果と良好 に対応するが，4 層相当の場合は，指針および解析に比 べ，低鉄筋比側では高目；高鉄筋比側では低目となる。

図一9に壁筋比が $0.32 \%$ と $0.64 \%$ に関し，女ん断 強度と壁の幅高さ比の関係を示す。A 法ではB法に比べ, 幅高さ比が大きく壁筋比が高いものほど，大きな強度を 与える。解析結果はすべて B 法を上回っているが，その 差は幅高さ比が大きく壁筋比が低いものほど小さい。換 言すれば幅高さ比が大きくなるとB法の安全率は低くな り, 壁の高さが 4 層相当以上では $\mathrm{A}$ 法は危険側の評価之 なる。

トラス機構負担分はB B法では壁の高さに無関係で一定 であるが，解析では壁が高くなるに従って大きくなり， 3〜4 層相当以上では B 法よりやや大きな值に収束する 傾向がある。A法では常に解析によりトラス機構を過大 評価するが，壁の高さが 1 層相当の場合にトラス機構が 減少する点では，解析結果と定性的に対応する。

広沢式は壁が低い場合は解析結果とほぼ対応するが, 壁が高くなると指針および解析より高目の評価となる。 壁の高さが低い場合に，広沢式と解析結果が対応する理 由は，広沢式の基となる実験デー夕はほとんどがシアス パン比 1.2 以下であったためと考えられる。

図一10 および 11 に壁の高さが 2 層と 4 層相当の場合 の解析による最大荷重近傍での各機構と側柱の負担分の 壁高さ方向の変化を示す。トラス機構負担分は壁の上下 端で水平方向の変形が拘束されるため, 壁の中腹で最大 となり，壁の幅高さ比および壁筋比の高いものほど大き い。一方, アーチ機構負担分は, 壁筋比が高くなると逆 に壁の中腹で小さ:くなる。側柱の負担分は引張側柱の柱 頭と圧縮側柱の柱脚で大きくなり，壁筋比が低いものほ ぼ，また壁の幅高さ比が大きいものほど，増大する傾向 にある。側柱の帯筋比は $0.6 \%$ であり, 解析ではこの
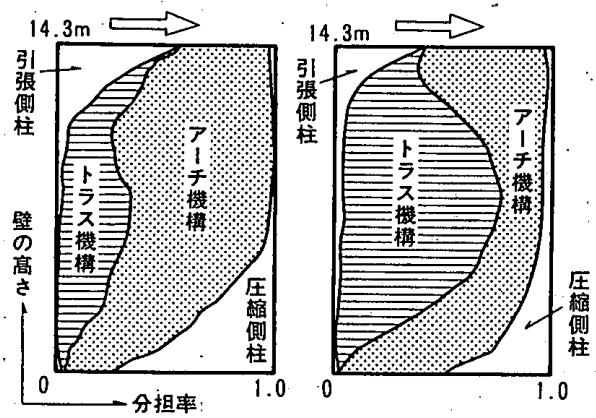

（a） C41(壁筋比 $0.32 \%$ ) (b) C43(壁筋比0.95\%)

図一11壁の幅高さ比が 1.84 (4 層相当) の場合の各機構と側 柱のせん断力分担率

部分にひびわれが生じたが，带筋は降伏せず，破壊には 至っていない。しかし側柱の端部ではせん断力のレベル が非常に高くなることから，実際の設計では十分な帯筋 を配しておくことが必要と思われる。

トラス機構の角度に関してては, 解析では主圧縮方向は 壁板内部で一様ではなく，特に背の高い壁ではひびわれ の角度が高さ方向で変化する扇形応力場となること，ま た主圧縮方向はアーチとトラスの両機構の合力に対する ものであることなどから，解析の主圧縮方向よりトラス 機構の角度を 1 つに特定することは困難と言える。そこ で，解析によるトラス機構負担分の最大值 $Q_{t u}$ より, トラス機構の角度 $\phi$ を次式により逆算することを試み た。

$$
\begin{aligned}
& \cot \phi=Q_{\imath u} /\left(t_{w^{*}} \cdot l_{w} \cdot p_{w^{*}{ }_{w}} \sigma_{y}\right) \\
& t_{w} \text { :壁厚 } \\
& l_{w}: \text { 壁内法長さ } \\
& p_{w} \text { : 壁横筋比 } \\
& { }_{w} \sigma_{y} ： \text { 壁筋の降伏点 }
\end{aligned}
$$

式 (1) で得られる結果は, トラス機構が最大となる水 平断面における平均的なトラスの角度と考えられる。

図一12 に算定結果を示す。壁の高さが 1 層相当の場 合はトラス機構負担分が極めて小さく，また壁筋比が $2.32 \%$ のものは壁横筋が降伏せずに耐力が決定したた め,これらはすべて除外した。解析結果から算定した $\cot \phi$ の值は, 壁の高さが 2 層相当の場合は $1.0 \sim 1.1$ 程度であるが，それ以上の高さでは $\mathrm{A}$ 法と $\mathrm{B}$ 法の中間の

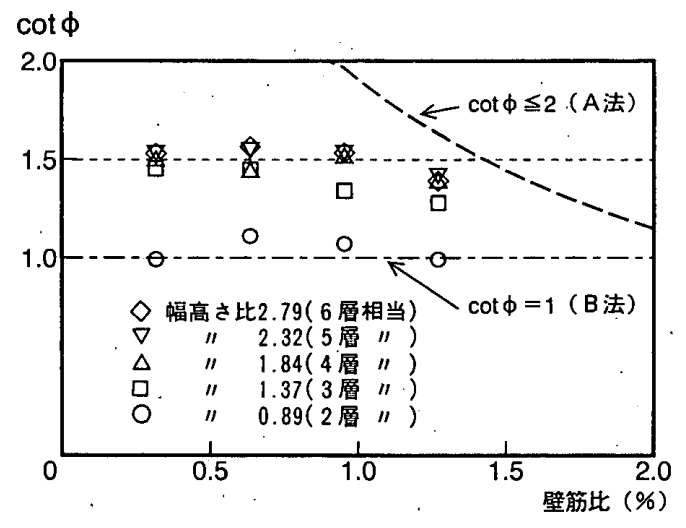

図一12 トラス機構の角度 $\phi$ の比較 


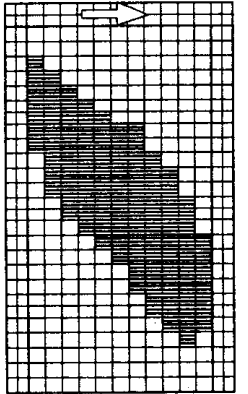

目横筋降优

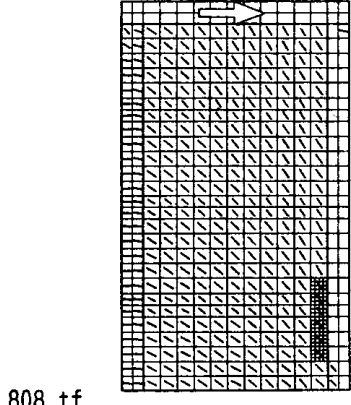

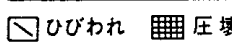

図一13 C 43（壁筋比 $0.95 \% ） の$ 壁筋降伏状況之破壊状況

1.5 前後の值を示し, 壁筋比の増大に伴い, やや小さく なる傾向にある。A法では本条件下で壁筋比が約 0.93 \%を超えるとアーチ機構が消滅してトラス機構のみと なり，コンクリートの有効強度の制限を受けて $\cot \phi$ が 2.0 より低下するが,この傾向は解析と対応している。

以上のように,解析結果は指針とやや異なる面があり, $\mathrm{A}$ 法とB法のいずれに近いとも言い難い。指針ではせん 断抵抗機構をトラスとアーチに明膫に分離した上で，壁 横筋とコンクリートが共にその強度に到達するとの前提 で耐力を求めている。一方, 解析ではトラスとア一チの 比率は壁の高さ方向で変化し，壁横筋の降伏とコンク リートの圧壊も，一般には図一13に示すようにその位 置がやや異なりこれらの傾向は背の高い壁になるほよ゙， 顕著となる。このような壁板内部の応力分布の違いが解 析と指針の対応性に影響していると考えられる。

\section{7. 中間ばりがせん断強度に及ぼす影堷}

指針では連層耐震壁は各層ごとに設計することとされ ており，上層のせん断力の一部を層間で構成するア一チ 機構により下層に伝達するのに必要な引張軸力を中間ば りで負担するように設計される。一方，連層耐震壁全体 を背の高い壁として扱い，中間ばりの主筋を壁横筋と同 様に扱うことで，耐力を良好に評価できるとの報告もあ る15)。本章では，中間ばりの有無と主筋量が連層耐震壁 のせん断強度に及ぼす影響を調べた。

\section{1 解析対象モデル}

解析対象と解析条件は前章までと同様で，壁の高さは 3 層および 5 層の 2 種類とした。中間ばりの有無とはり 主筋量をパラメータとし，中間ばりの断面は設計例どお りとした。壁横筋と中間ばりの主筋は同一鉄筋とし，そ れらの総量は一定で，壁横筋のみの場合に $0.95 \%$ とし た。壁縦筋はすべてのケースで $0.95 \%$ とした。

解析ケース名はD 32 のようにすべて Dで始まり，2 番 目の数字は層数（壁の高さ）を表し， 3 番目の数字は次 の要領で壁横筋比とはり主筋比（括弧内）を表す。

$$
\begin{array}{llll}
0: 0.0 \%(1.79 \%) & 1: 0.32 \%(1.33 \%) \\
2: 0.64 \% & (0.88 \%) & 3: 0.95 \% & (0.42 \%)
\end{array}
$$

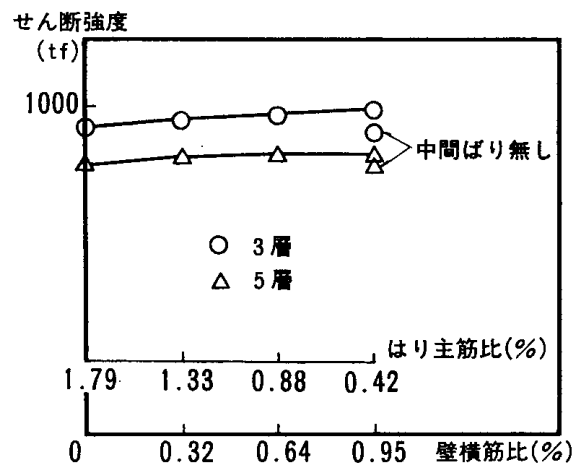

図一-14 中間ばりの有無と主筋量がせん断強度に及ぼす影響
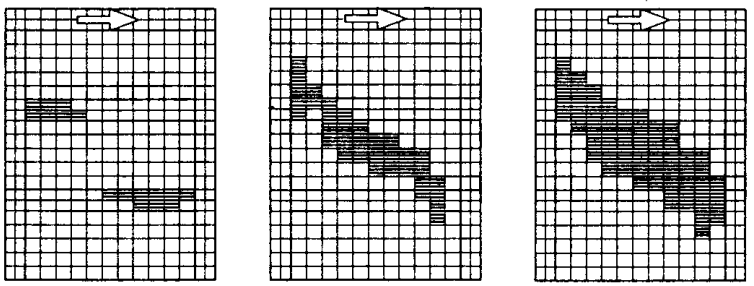

自棤敏降伏

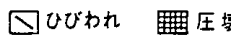

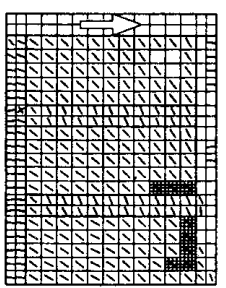

D30 (はり主筋比 $1.79 \%)$ $896 \mathrm{tf}$ 時

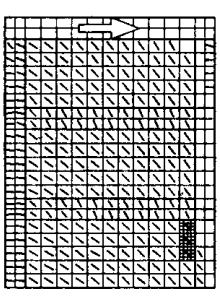

D33 (はり主筋比 $0.42 \%$ ) $885 \mathrm{t}+$ 時

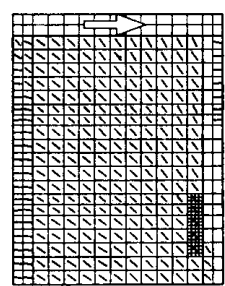

C33 (中間ばり無し 867 tf時
図一15 中間ばりの有無と主筋比の違いによる破壊性状の比較

はりの引張軸力 $(\mathrm{t} f)$

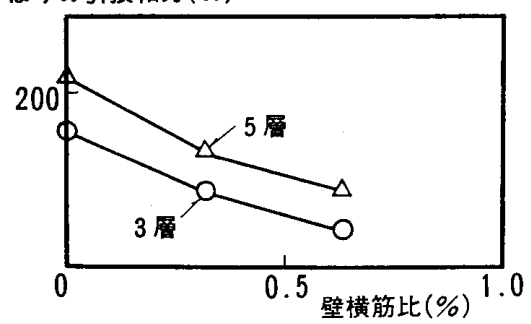

図一16 中間ばりの引張軸力の比較

中間ばりの無いケースは前章でのC 33 と C 53 である。

\section{2 解析結果の検討}

図一14 に最大荷重の比較を示す。壁横筋をすべては り主筋として集中配筋したものに比へ，壁横筋の比率を 大きくしたものの方が耐力が高くなるが，その差は 3 層 の場合で約 $6 \%$ ，5層の場合で約 $3 \%$ 程度であり，壁が 高くなるほじ，小さくなる傾向がある。はり型の無いも のは，3 層では約 $7 \% ， 5$ 層では $4 \%$ 程度耐力が低くな る。

図一15に 3 層の代表的なケースの鉄笳降伏と破壊状 況の比較を示す。中間ばりがあるD 30 とD 33 では，は りのひびわれが鉛直に近くなり，はりが軸方向引張力を 受けていることが分かる。鉄筋降伏は中間ばりが無い 

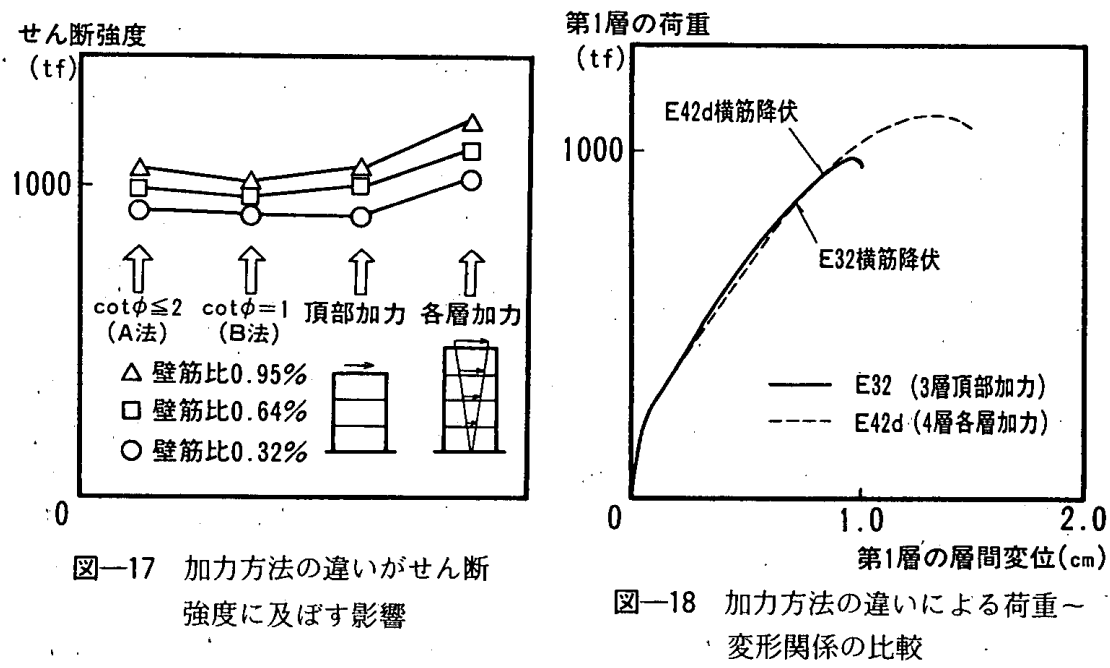

C 33 で最も広範囲に生じるが，いずれも頂部引張側か ら脚部圧縮側に向かう対角線に沿う領域で発生してい る。コンクリートの圧壊領域に㪟著な差は認められない。

指針のように各層ごとに設計すると，はり主筋は直接 にはせん断強度に寄与しないが，解析では壁横筋とほぼ 同等の寄与が見られた。はり主筋位置での集中的横補強 法の有効性は吉崎ら ${ }^{28}$ により実験的にも示されている。

図一16 は解析で中間ばりに作用した引張軸力の最大 值を比較したものである。解析では壁の中腹にあたる部 分の中間ばりのスパン中央部付近で最大值を示した。横 筋比の増加に伴い, 中間ばりの引張軸力が低下しており, 壁筋によるトラス機構負担分の増大により層間アーチ機 構の負担分が減少していることが分かる。3 層より 5 層 の方が引張軸力がやや大きいが，これははりをトラスの 引張材と見なした場合に，壁の幅高さ比が大きい方が全 体アーチ機構の負担分が減り, トラス機構（層間アーチ 機構）の負担分が大きくなるためと考えられる。

\section{8. 高さ方向の水平力分布がせん断強度に及ぼす影響}

一般に連層耐震壁は地震時に各層でせん断力を受ける ため; 下層部ほど，せん断力のレベルが高くなる。水平 力を逆三角形分布で各層に加力した実験では, 頂部加力 に比較して等価なシアスパン比が小さくなるため, 耐力 が高くなるものと考えられている17!。本章では等価なシ アスパン比が等しい場合に, 高さ方向の水平力分布の違 いが連層酎震壁のせん断強度に及ぼす影響を調べた。

\section{1 解析対象モデル}

解析対象は前章と同様であるが, 壁の高さは頂部加力 の場合に 3 層とし，逆三角形分布で各層加力の場合には 合力によるシアスパン比が等しくなる 4 層とした。中間 ばりの断面と主筋量は指針の設計例どおりとし, 壁筋比 を設計例の值を中心に変化させた。いずれも最上層のは りは剛体とし，中間層への加力は，4.1で述べたはりへ の分布載荷形式とした。解析ケース名は E 31 のように すべて $\mathrm{E} て ゙$ 始まり，2 番目の数字は壁の層数を表し， 3

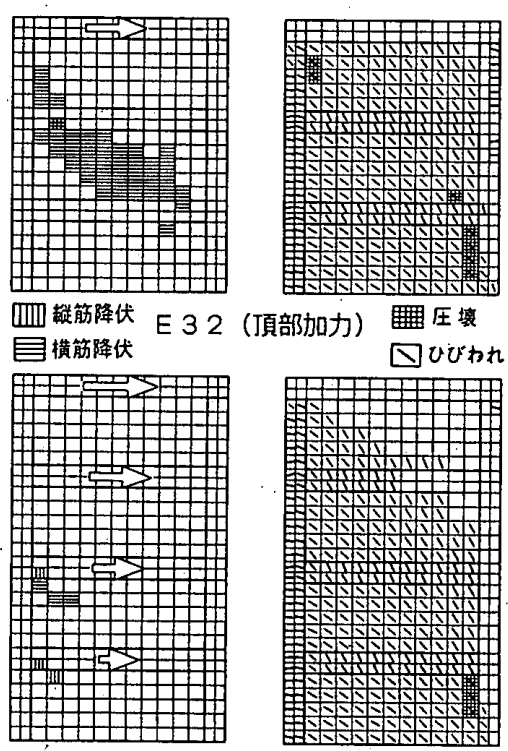

E 4 2d（各層加力）

$934 \mathrm{tf}$

図一19 加力方法の違いによる 破壊性状の比較

番目の数字は次の要領で壁筋比を表す。

$$
1: 0.32 \% \quad 2: 0.64 \% \quad 3: 0.95 \%
$$

各層加力の場合は末尾に.d を付す。

\section{2 解析結果の検討}

図一17に耐力の比較を示す。頂部加力の場合に比較 して各層加力では約 11 13\% 程度耐力が高い。指針に よる第1 1 層の耐力は頂部加力の場合にほぼ等しくなり, 各層加力に対しては安全側の結果を与える。

図一 18 に E 32 と $\mathrm{E} 42 \mathrm{~d}$ の第 1 層の荷重一層間変位関 係を示す。最大荷重までの頂部加力の結果は各層加力の 結果とほぼ一致し,他の壁筋比に関しても同様であった。

図一19にE 32 と E $42 \mathrm{~d}$ のほぼ等しい荷重レベルにお ける鉄筋降伏状況と破壊状況の比較を示す。最も大きな 違いは, 壁横筋の降伏が頂部加力の場合に第 2 層で顕著 であるのに対し，各層加力ではわずかな点である。これ は上端では剛ばり，下端では固定条件により水平方向に 拘束されるが，壁の中腹付近では拘束の影響が小さくな るため, 第 2 層の作用せん断力がより大きい頂部加力の 場合に横筋の降伏が生じやすくなるものと考えられる。 また，コンクリートの圧壊は各層加力では第 1 層の圧縮 側のみであるが，頂部加力の場合には各層において生じ ている。これらが耐力に差を生じさせた原因と考えられ る。

\section{9. 結 論}

連層耐震壁を含む比較的シアスパン比の大きな耐震壁 を主対象として，せん断強度に関する解析的検討を行い， 以下の知見を得た。

1）頂部のはりの剛性が壁のせん断強度に及ぼす影響 は，3 層程度以上の壁高さではほとんど影響がない。 
2）高強度鉄筋の使用などによる引張側柱の主筋量の減 少は壁のせん断強度の低下を招くおそれがある。

3）解析によるせん断強度に対しては，B法では壁の幅 高さ比が大きくなると安全率が小さくなり，A法では 3 層程度以上で危険側の評価となる。

4）解析のトラス機構負担分は壁の高さが 3 層程度以上 ではB法よりやや大きく，A法では過大評価となる。

5）解析結果より逆算したトラス機構の角度 $\phi$ は, 壁 の高さが 3 層程度以上では $\cot \phi=1.5$ 程度となる。

6）壁横筋と中間ばりの主筋の総量が等しければ，はり 主筋量の差が壁のせん断強度に及ぼす影響は小さい。

7）解析で中間ばりに作用する引張軸力は，層数が少な いものほど,また壁横筋比が大きいものほど, 低下する。 8）等価なシアスパン比が等しい場合, 各層加力より頂 部加力の方が中間層における壁横筋の降伏が顕著とな り，せん断強度が低下する。

以上，限定された条件下で得られた結果ではあるが, これらより判断すると連層耐震壁は各層ごとに設計する

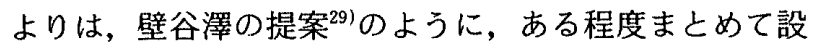
計した方がより合理的であると考えられる。しかし，現 指針では連層耐震壁のように背の高い壁のせん断強度の 算定には検討の余地があり, より実際のせん断抵抗機構 に即した力学モデルの構築が必要と言える。

\section{謝 辞}

本論文の作成に当たり, 御指導, 御助言を頂いた千葉 大学 野口 博教授に深く感謝の意を表します。

\section{参考文献}

1）片桐 徹, 望月 洵, 小野里悪一: 背高な連層耐震壁の 強度之变形, 日本建築学会大会学術講演梗概集, 構造 II, pp. 579 580, 1990. 10

2）金本清臣，松本和行，壁谷澤寿海：高強度材料を用いた 曲げ降伏型鉄筋コンクリート耐震壁の復元力特性（その 1, その 2), 日本建築学会大会学術講演梗概集, 構造 II, pp. $607 \sim 610,1990.10$

3）松本和行，壁谷澤寿海，倉本 洋：シアスバン比の大き い高強度鉄笳コンクリート耐震壁の静加力実験, コンク リート工学年次論文報告集, Vol. 14, No. 2, pp. 819 824, 1992.6

4）柴田拓二ほか 3 名：鉄筋コンクリート造連層酎震壁の変 形挙動（その $1 \sim そ の 3)$, 日本建築学会大会学術講演梗 概集，構造 II，pp. 573 578，1990.10

5）牧田敏郎ほか 3 名：曲け降伏型連首耐震壁に関する実験 的研究, コンクリート工学年次論文報告集, Vol. 12, No. 2, pp. 551 556, 1990.6

6）菅野俊介, 長鴄俊雄, 木村秀樹: 高強度コンクリート耐 震壁の強度と变形性能に関する実験的研究, 日本建築学 会大会学術講演梗概集，構造 II, pp. 437 438, 1991.9

7） 日本建築学会：建築耐震設計における保有耐力と变形性 能, 第 2 版, 1990

8) 白井伸明, 白石一郎, 村上利憲: $\mathrm{RC}$ 耐震壁の終局強度 に関する既往のマクロモデルについて， RC 耐霞壁のマ
クロモデルと FEM ミクロモデルに関するパネルディス カッション論文集, JCI-C 11, pp. 5 20, 1988.1

9） 日本建築学会：鉄筋コンクリート造建物の終局強度型耐 震設計指針・同解説, 1990

10）范 啓民, 野口 博：鉄筋コンクリート造耐震壁のデー タベースによるせん断強度, 終局変形の AIJ 指針式に関 する考察, 日本建築学会大会学術講演梗概集, 構造 II, pp. 339 340, 1992.8

11) 白石一郎, 狩野芳一, 町田亘寛: 鉄筋コンクリート造耐 震壁の最大せん断耐力に関する一考察, 日本建築学会構 造系論文報告集，第 365 号，pp. 144 155，1986.7

12）白石一郎，中村善郎，狩野芳一：鉄筋コンクリート造耐 震壁の最大耐力への壁筋の効果, 日本建築学会構造系論 文報告集，第 392 号，pp. 34 45, 1988. 10

13）植松卓二, 高木仁之, 狩野芳一：FEM 解析による鉄筋 コンクリート耐震壁のせん断耐力に関する検討，コンク リート工学年次論文報告集, Vol, 13, No. 2, pp. 553 558, 1991.6

14）望月 洵, 片桐 徹, 梅田正芳：連層耐婯壁のせん断破 壊に及ぼす柱の拘束の効果について, 日本建築学会大会 学術講演梗概集, pp. 391 392, 1987.10

15）高木仁之，茂呂田雅之，狩野芳一：せん断破填先行型耐 震壁のせん断強度に及ぼす中間梁の効果に関する実験的 研究 (その 1 , その 2 ), 日本建築学会大会学獄講演梗概集, pp. 243 246, 1987.10

16）鈴木紀雄：鉄筋コンクリート造連層耐震壁における中間 梁の効果に関する解析的検討，コンクリート工学年次論 文報告集, Vol. 12, No. 2, pp. 587 590, 1990.6

17）佐藤稔雄ほか 4 名：鉄筋コンクリート造耐震壁の弾塑性 性状に関する研究 (その 9, その10), 日本建築学会大会 学術講演梗概集, pp. 1623 1626, 1980.9

18）井上範夫, 白石一郎, 野口 博: FEM 上よる $\mathrm{RC}$ 耐震 壁のマクロモデル検証の試み， $\mathrm{RC}$ 耐震壁のマクロモデ ルとミクロモデルに関するパネルディスカッション論文 集, JCI-C 11, pp. $67 \sim 80,1988.1$

19）飯塚崇文, 野口 博：普通強度から高強度までの材料を 用いた鉄筋コンクリート部材の非線形有限要素解析, コ ンクリート工学年次論文報告集, Vol. 14, No. 2, pp.9 $14,1992.6$

20）長沼一洋：鉄笳コンクリート壁状構造物の非線形解析手 法に関する研究（その1）平面応力場に㧍ける鉄筋コン クリート板の非線形解析モデル，日本建築学会構造系論 文報告集，第 421 号，pp. 39 48, 1991.3

21）長沼一洋：鉄筋コンクリート壁状構造物の非線形解析手 法に関する研究 (その2) 鉄筋コンクリート耐震壁の非 線形解析手法之適用性, 日本建築学会構造系論文報告集, 第 431 号, pp.7 16, 1992.1

22）狩野芳一，高木亿之：鉄筋コンクリート造耐霞壁の耐震 性能に関する総合研究 (その10), 日本建築学会大会学 術講演梗概集, pp. 1607 1608, 1976. 10

23）狩野芳一，高木仁之：鉄筋コンクリート耐震譬の梁効果 に関する実験的研究, 日本建築学会大会学術鿁演梗概集, pp. 1415 1416, 1977. 10

24）高木仁之ほか 3 名：連層鉄筋コンクリート耐震壁のせん 断強度に及ぼす中間梁の効果に関する実験的研究（その 3 ), 日本建築学会大会学術講演梗概集, pp. $541 \sim 542$, 1988. 10 
25）佐藤稔雄ほか 5 名：鉄筋コンクリート造耐霞壁の弾塑性 性状に関する実験研究（その3), 日本建築学会大会学術 講演梗概集, pp. 1609 1610, 1978.9

26）小野 新, 安達 洋, 中西三和：鉄筋コンクリート造耐 震壁の弾塑性性状に関する研究 (その8), 日本建築学会 関東支部研究報告集, pp. 121 124，1979

27）井上範夫ほか 3 名：鉄筋コンクリート壁の㓦震機構に関 する研究 (その 1 , その 2 ), 日本建築学会大会学術講演 梗概集，pp. $385 \sim 388 ， 1987.10$

28）吉崎征二，金田和浩：新補強法を用いた鉄筋コンクリー 卜耐震壁の性状, コンクリート工学論文集, Vol. 3, No. 1, pp. 23 31, 1992.1.

29）壁谷澤寿海：連層耐震壁の設計法, 日本建築学会大会学 術講演梗概集，構造 II，pp. 357 358，1992.8

(1992 年 9 月 7 日原稿受理, .1993 年 2 月 8 日採用決定) 